\title{
Pendampingan Model Pembelajaran Inovatif menggunakan Kahoot sebagai Digital Game Based Learning di KKG Sekolah Dasar
}

\author{
Feby Inggriyani $^{1}$, Nurul Fazriyah ${ }^{2}$, Acep Roni Hamdani ${ }^{3}$, Ayi Purbasari ${ }^{4}$ \\ ${ }^{1,2,3}$ PGSD, FKIP, Universitas Pasundan \\ ${ }^{4}$ Teknik Informatika, Universitas Pasundan \\ 1 febyinggriyani@unpas.ac.id \\ nurulfazriyah@unpas.ac.id \\ 3acepronihamdani@unpas.ac.id \\ ${ }^{4}$ pbasari@unpas.ac.id
}

\begin{abstract}
ABSTRAK
Mita PKM adalah KKG 066 Kecamata Lengkong Kota Bandung yang memiliki permasalahan dalam menciptakan pembelajaran inovatif dan minimnya pemahaman guru dalam pembelajaran digital. Kegiatan ini bertujuan untuk membantu KKG dalam meningkatkan pengetahuan dan keterampilan menggunakan model pembelajaran inovatif dengan menggunakan literasi digital sehingga dapat meningkatkan kualitas pembelajaran. Metode kegiatan ini dilakukan dengan workshop dan pendampingan yang mencakup dua pendekatan yaitu pendekatan teoretis dan praktis. Pendekatan teoretis dengan menjelaskan mengenai model pembelajaran inovatif dan penggunaan kahoot dalam pembelajaran. Pendekatan praktis dilakukan dengan menyiapkan rencana pembelajaran (RPP) menggunakan model pembelajaran inovatif dengan menggunakan kahoot. Hasil yang diperoleh melalui kegiatan ini adalah 1) meningkatkan pengetahuan guru tentang model pembelajaran inovatif dan menggunakan kahoot dalam pembelajaran, 2) meningkatkan pengetahuan guru dalam membuat rencana pembelajaran (RPP) dan 3) meningkatkan keterampilan menggunakan model pembelajaran inovatif dengan penggunakan media pembelajaran digital berbasis game.
\end{abstract}

Kata Kunci : kahoot, model pembelajaran inovatif, pembelajaran berbasi game

\section{ABSTRACT}

Mita PKM is a KKG 066 in Lengkong Sub-District of Bandung which has problems in creating innovative learning and the lack of understanding of teachers in digital learning. This activity aims to assist the $K K G$ in increasing knowledge and skills using innovative learning models by using digital literacy so as to improve the quality of learning. This activity method is carried out with workshops and mentoring which includes two approaches namely theoretical and practical approaches. Theoretical approach by explaining about innovative learning models and the use of kahoot in learning. A practical approach is carried out by preparing a learning plan (RPP) using an innovative learning model using kahoot. The results obtained through this activity are 1) increasing teacher knowledge about innovative learning models and using kahoot in learning, 2) increasing teacher knowledge in making learning plans (RPP) and 3) improving skills using innovative learning models by using game-based digital learning.

Keywords: kahoot, innovative earning model, games based learning

\section{PENDAHULUAN}

Guru merupakan faktor penentu keberhasilan siswa dalam belajar dan kesukseskan tersebutlah yang menentukan guru harus bisa memilih salah satu model pembelajaran inovatif yang tepat dalam pembelajaran. Hal ini disebabkan karena setiap model pembelajaran memiliki kelebihan dan kekurangan. Oleh karena itu, guru harus kreatif dan selektif dalam memilih model pembelajaran inovatif yang disesuaikan dengan karakteristik peserta didik, prinsip belajarnya dan jenjang pendidikannya.

Pembelajaran inovatif merupakan pembelajaran yang lebih bersifat student centered dengan memberikan peluang kepada peserta didik untuk lebih mengkonstruksi pengetahuan secara mandiri. Model ini perlu diterapkan untuk mempersiapkan guru dalam menghadapi abad 21 (Zain, 2017) sehingga pembelajaran yang inovatif dapat membawa pengaruh positif pada kinerja peserta didik yang bermacam-macam karakteristik (Naz \& Murad, 2017) dan dengan melibatkan penggunaan teknologi didalam menyajikan inovasi pada setiap model pembelajaran yang dipilihnya (Lee, 2011; Naga Subramani \& Iyappan, 2018)Dengan demikian, guru harus literat dan menyesuaikan dengan perkembangan abad 21 yang berbasis revolusi 4.0 dalam teknologi pembelajarannya. 
Revolusi industri 4.0 ini sangat merubah semua sektor dan membawa pengaruh yang signifikan terhadap setiap perubahan terutama pendidikan sehingga menuntut guru untuk merubah kegiatan pembelajarannya dengan berkolaborasi menggunakan internet. Dengan demikian, perkembangan teknologi menuntut guru untuk mengubah media ajarnya konvensional menjadi media digital dan mampu membentuk peserta didik menjadi mandiri, berpikir kritis, mampu berkomunikasi, menggunakan teknologi dan berkolaborasi dengan orang lain. Oleh karena itu diperlukan sebuah media belajar berbasis digital untuk meningkatkan performa belajar siswa dengan multimedia yang menarik baik dari audio maupun visualnya. Salah satunya dengan kahoot yang merupakan sebuah laman daring dengan menggunakan internet dan sangat edukatif dikarenakan menyediakan fitur-fitur sebagai media inovatif dalam kegiatan proses pembelajaran (Irwan, Irwan \& Waldi, 2019) Hal ini disebabkan karena media memudahkan didalam penyampaikan pesan pengetahuan sehingga penyampaiannya harus menarik perhatian siswa sehingga dapat membangkitkan minatnya pada pelajaran dan diharapkan dapat mempercepat pemahaman siswa dalam proses pembelajaran (Tuken, 2013).

Penggunaan platfotm kahoot dalam pembelajaran dapat membantu aktivitas evaluasi pembelajaran menjadi menarik, interaktif, dan kondusif dikarenakan proses pembelajarannya dengan adanya permainan serta mudah dalam memonitaring hasil belajar peserta didiknya, dikarenakan hasilnya dapat terlihat secara langsung oleh guru. Adapun penggunakan kahoot dengan karakteristik multiplayer dapat memfasilitasi interaksi anak dengan lingkungan sosialnya di dalam kelas dalam bentuk permainan yang dapat memengaruhi perkembangan sosial emosional anak dalam kemampuan berkompetisi dan berkolaborasi (Rofiyarti, 2017). Oleh karena itu, guru harus memiliki soft skill dan hard skill dalam pembelajaran sehingga mampu berkompetensi di era 4.0.

Mitra PKM ini adalah KKG Gugus 066 Kecamatan Lengkong Kota Bandung yang merupakan wadah didalam pembinaan profesional guru mengenai permasalahan yang berkaitan dengan kompetensi pedagogik, profesional, kepribadian dan sosial antar guru untuk merencanakan, melaksanakan dan menilai kemajuan peserta didik sehingga berdampak pada perbaikan pembelajaran dan peningkatan prestasi peserta. Kantor pusat KKG
Gugus 066 ini berada di Jl. Halimun No.45 Kecamatan Lengkong Kota Bandung dengan ketuanya yaitu Hj. Nenden YH, S.Pd., M.M KKG Gugus 066 terdiri dari 9 SD yaitu SDS BPI, SDN Halimun, SDS BPK Penabur, SDN Lengkong Kecil, SDS Gagas Ceria, SDS Al Azhar, SDS Kemala Bhayangkari, SDS Cipaera dan SDS IRK.

Berdasarkan hasil wawancara dan observasi di KKG Kecamatan Lengkong Kota Bandung diperoleh fakta bahwa pembelajaran yang dilakukan guru masih monoton sehingga siswa terlihat bosan dalam pembelajaran, RPP yang dibuat masih konvensional dalam langkah pembelajarannya dan kurangnya kreativitas guru dalam menciptakan media ajar berbasis teknologi informasi didalam pembelajarannya serta penilaiannya belum otentik dan belum mencerminkan penilain berbasis HOTS (Higher Order Thinking Skills). Hal ini terjadi karena sebagian guru belum mampu merancang perangkat pembelajaran yang berorientasi pada model pembelajaran inovatif. Dengan demikian, guru-guru perlu mendapatkan pendampingan penggunaan model pembelajaran inovatif dan penggunakan literasi digital melalui kahoot sebagai game base learning untuk peningkatan kompetensi dalam merancang, melaksanakan proses pembelajaran inovatif, dan menilai secara otentik setiap pembelajaran yang dilakukannya.

Solusi yang ditawarkan untuk menyelesaikan masalah mitra di KKG Gugus 066 Kecamatan Lengkong Kota Bandung adalah pendampingan penggunaan model pembelajaran inovatif dan pendampigan penggunaaan literasi digital menggunakan kahoot sebagai media pembelajaran yang menyenangkan bagi peserta didik. Tujuannya adalah supaya KKG dapat menciptakan pembelajaran inovatif dan menyenangkan susuai dengan tuntutan 4.0.

\section{METODE KEGIATAN}

Metode pelaksanaan kegiatan dimulai dari pendahuluan, pelaksanaan, evaluasi dan refleksi,serta tindak lanjut. Subjeknya adalah KKG di Gugus 66 Kecamatan Lengkong Kota Bandung dengan 18 orang guru kelas tinggi dari perwakilan 9 sekolah negeri dan swasta. Sedangkan metode pendekatan meliputi workshop dan pendampingan. Workshop berisi teoritik dengan memberikan materi modelmodel pembelajaran inovatif dan langkahlangkah pembelajarannya. Tahap kedua yaitu pendampingan dengan melakukan praktik untuk menyusun rencana pelaksanaan 
pembelajaran (RPP) menggunakan salah satu model pembelajaran. Kegiatan ini bertujuan untuk melatih keterampilan KKG dalam menyusun dan membuat model pembelajaran inovatif dengan rancangan yang akan dibuat dalam RPP dengan bantuan media pembelajaran kahoot berbasis digital games based learning. Setelah itu, memilih salah satu guru untuk menjadi model dalam pembelajaran dan tahap 3 implementasi mengajar di kelas yang dilakukan oleh guru model.

Kegiatan workshop dan pendampingan dievaluasi dengan diberikannya soal pre test dan post test mengenai materi model-model

\section{Permasalahan Mitra:}

KKG belum memiliki pengetahuan dan keterampilan mengenai modelmodel pembelajaran inovatif dan penggunaan media kahoot sebagai games based learning pembelajaran inovatif dan fungsi literasi digital menggunakan media interaktif berbais games based learning untuk mengetahui peningkatan dari awal kegiatan sampai akhir kegiatan. Setelah itu, tim pengabdian melakukan pendampingan lanjutan untuk memperdalam pemahaman guru didalam menyusun dan melaksanakan model pembelajaran inovatif dan adanya tindak lanjut dengan memberikan rak dan buku mengenai model pembelajaran dan buku literasi digital untuk membantu guru dalam merencanakan dan melaksanakan kegiatan pembelajaran di kelas sehingga menjadi lebih efektif dan menyenangkan

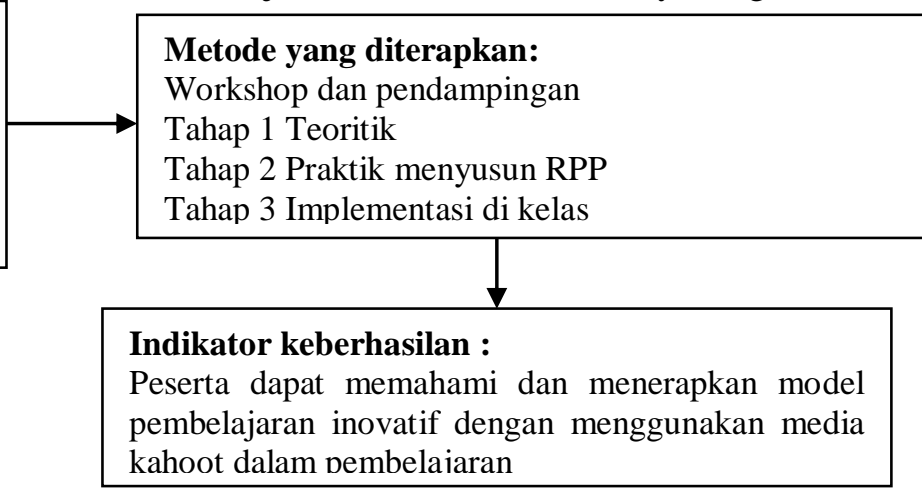

Gambar 1 Tahapan Kegiatan Pengabdian Masyarakat

\section{HASIL \& PEMBAHASAN}

Materi yang disampaikan meliputi konsep dan langkah-langkah dari model pembelajaran inovatif berbasis kurikulum 2013, STEM dan kahoot sebagai media yang dapat meningkatkan kualitas peningkatan hasil belajar peserta didik. Dampak dan manfaat kegiatan ini adalah peserta kegiatan dapat mengetahui dan mampu menerapkan model-model pembelajaran inovatif di kelasnya sehingga pembelajaran tidak monoton, menumbuhkan semangat belajar peserta didik, meningkatkan minat dan motivasi belajar, kemandirian belajar serta hasil belajarnya semakin meningkat. Pada saat pelaksanaan pemaparan materi kegiatan workshop, peserta kegiatan sangat antusis untuk menyimak apa yang disampaikan narasumber serta banyak diantaranya yang aktif untuk bertanya mengenai cara pengelolaan kelas dengan menggunakan model pembelajaran inovatif serta cara menerapkan STEM untuk kegiatan pembelajaran supaya kelas menjadi lebih hidup serta penyusunan RPP pembelajaran inovatif dan penggunaan media interaktif kahoot sebagai pendukung media literasi digital dalam pembelajaran untuk meningkatkan motivasi belajar peserta didik. Berikut foto kegiatannya:

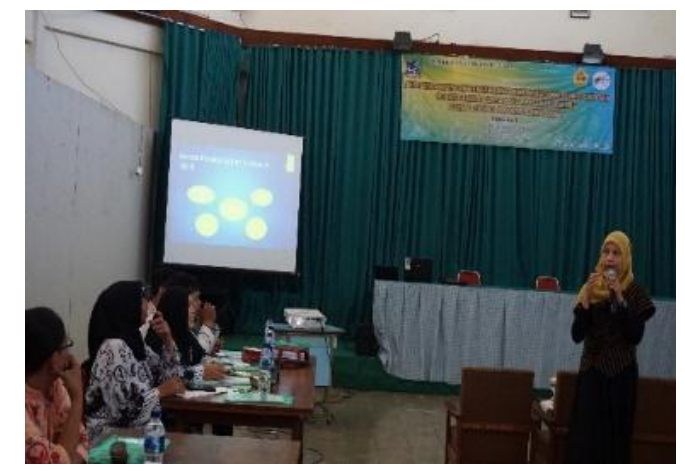

Gambar 2. Pemaparan materimodel pembelajaran inovatif

Setelah kegiatan workshop, tim pengabdian pun melakukan pendampingan dengan guru didalam penyusunan RPP model pembelajaran inovatif dan langkah-langkah pelaksanaan pembelajarannya. Guru pun sangat semangat, antusias dan menikmati setiap proses pendampingan. Hal ini disebabkan karena, selama ini sebagian guru masih ada yang mengajar dengan menggunakan teacher center dan terkadang menggunakan pendekatan student center. Namun, sebagian guru masih belum jelas didalam langkah-langkah pelaksanaannya karena belum memahami dengan seksama. Oleh karena itu, dengan adanya workshop dan pendampingan sangat membantu guru dalam meningkatkan kualitas pembelajaran menjadi hidup dan bermakna dan menyenangkan. Selain itu, lebih mengetahui 
pengetahuan dan pemahaman dalam mengaplikasikan media pembelajaran sebagai penunjangnya yaitu melalui kahoot sebagai media pembelajara berbasis digital game based learning yang dapat dioptimalkan untuk meningkatkan motivasi dan kemandirian peserta didik dan dimanfaatkan untuk memudahkan proses evaluasi pembelajaran serta konten kahoot dapat dibuat untuk mendorong peserta didik mendalami setiap materi yang diajarkan yang tidak hanya untuk pembelajaran didalam kelas, namun dapat dimanfaatkan sebagai tugas belajar yang dapat dikerjakan diluar kelas (Putri \& Muhammad Alie Muzakki, 2019). Oleh karena itu, inovasi pembelajaran sangatlah penting dan menarik untuk dilakukan guru dikarenakan untuk menyesuaikan dengan pembelajaran abad 21 dengan ciri adanya sistem komputasi dalam pembelajaran yang menyebakan pergeseran paradigma menuju meta knowledge dan yang kedua masuknya era digital yang melibatkan segala proses kehidupan sehingga salah satunya dapat meningkatkan minat peserta didik dalam belajar (Bennett, 2018; Kereluik et al., 2013; Putri \& Muhammad Alie Muzakki, 2019).

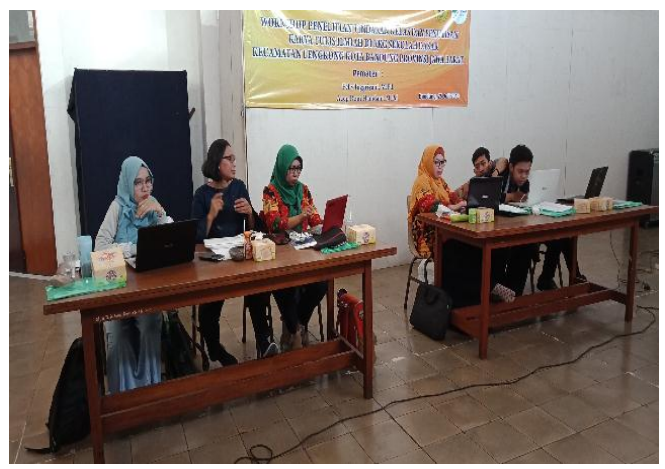

Gambar3. Praktik membuat RPP model pembelajaran inovatif

Peserta kegiatan workshop dan pendampingan terdiri dari perwakilan kelas IV dan V di KKG 66 Sekolah Dasar Kecamatan Lengkong yaitu 18 peserta dan semuanya mengikuti kegiatan dari awal sampai akhir. Dengan demikian dapat dikatakan bahwa target peserta tercapai $100 \%$. Artinya, kegiatan pengabdian dilihat dari jumlah peserta yang mengikutinya dapat dikatakan berhasil. Berdasarkan hasil kegiatan tersebut diperoleh data pre tets sebesar $42 \%$ dan setelah diberikan materi menjadi $77 \%$ dan adanya peningkatan pengetahuan sehingga adanya peningkatan pengetahuan dan keterampilan peserta sebesar $35 \%$. Dengan demikian, kegiatan workshop dan pendampingan model-model pembelajaran inovatif menggunakan literasi digital melalui media interaktif kahoot dapat meningkatkan pemahaman dan pengetahuan KKG 066 Kecamatan Lengkong Kota Bandung dalam mengimplementasikan model pembelajaran inovatif dalam kegiatan pembelajaran. Hal ini sesuai dengan hasil dari pengabdian kepada masyarakat yang dilakukan (Yuliati, 2018) bahwa kemampuan peserta setelah mengikuti kegiatan pelatihan adalah peningakatan dalam menguasai materi model pembelajaran inovatif dan memberikan kontribusi positif kepada kesadaran guru untuk melakukan perbaikan dengan menggunakan model pembelajaran inovatif dan media pembelajaran yang dapat mengaktifkan peserta didik didalam kelas dan menciptakan kegiatan pembelajaran yang menyenangkan.Berikut dianrara foto kegiatan pendampingan mengenai literasi digital dalam pembelajaran dengan menggunakan kahoot:

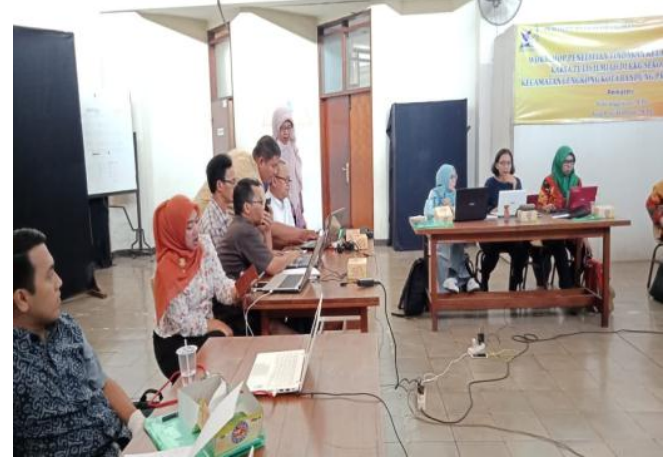

Gambar 4. Pendampingan praktik pembuatan konten pembelajaran dalam kahoot

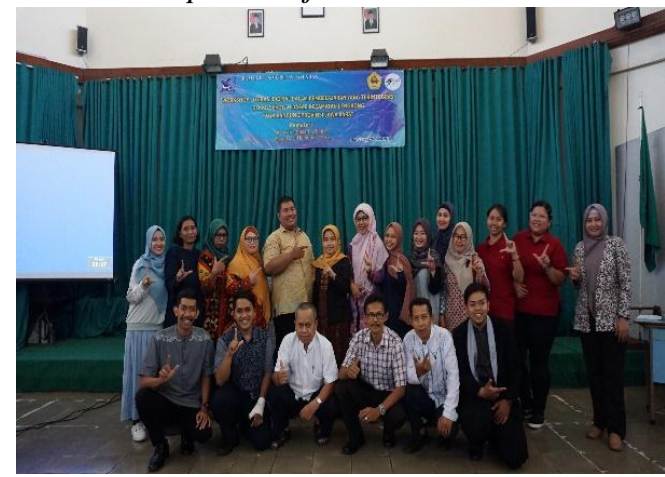

Gambar 5. Poto bersama peserta workshop dan pendampingan

Terdapat faktor pendukung kegiatan PKM ini yaitu adanya dukungan dari ketua gugus 066 untuk mengadakan kegatan yang dapat membantu guru dalam memecahkan masalah pembelajaran untuk meciptakan pembelajaran yang menyenangkan dan bermakna serta terdapat tantusiasme guru untuk mengikuti kegiatan penerapan model pembelajaran inovatif sehingga kegiatan ini berjalan dengan efektif dan interaktif. Adapun faktor yang menghambat kegiatan ini adalah 1) adanya berbagai aktivitas guru sehingga kegiatan pendampingan menyesuaikan 
waktunya dengan kondisi guru dan sekolah , 2) keterbatasan waktu dan membuat tidak semua peserta mengikuti kegiatan pendampingan dan praktik dengan bimbingan terarah untuk mengimplementasikan model pembelajaran inovatif dengan menggunakan literasi digital melalui kahoot, dan 3). Sebagian guru menjelaskan bahwa pembelajaran ini menyenangkan namun mereka kesulitan dalam implementasinya, dikarenakan kurangnya sarana dan prasarana yang memadai, tidak semua peserta didik memiliki telepon selular android dan jaringan internet yang kurang terjangkau di kelas. Namun, hal tersebut tidak menurunkan semangat KKG untuk kreatif dalam pembelajaran. Hal ini sesuai dengan hasil pengabdian (Sugiarni \& Kurniawati, 2019) yang menjelaskan, bahwa terdapat kesulitan didalam implementasi hasil kegiatan pelatihan yaitu, minimnya sarana dan prasarana sekolah yang dimiliki terutama internet dan $\mathrm{hp}$ dari masing-masing peserta didik dan hal tersebut tidak menurunkan semangat para guru untuk menciptakan pembelajaran dengan menerapkan keterampilan $4 \mathrm{C}$ melalui pemanfaatkan sarana dan prasarana yang ada untuk mengikuti penggunaan teknologi selama proses pembelajaran sesuai dengan tantangan abad 21. Setelah itu, tim pengabdian memilih salah satu guru KKG 066 Kecamatan Lengkong untuk mengimplementasikan salah satu model pembelajaran dengan menggunakan literasi digital menggunakan media game based learning yaitu kahoot untuk penilaian hasil belajaranya. Guru yang tepilih adalah pa Sulaeman, S.Pd dari SDN Halimun yang mengajar di kelas IV. Berikut beberapa aktivitas kegiatan praktik model pembelajaran inovatif menggunakan literasi digital berbasis kahoot yang dilakukan oleh guru model:

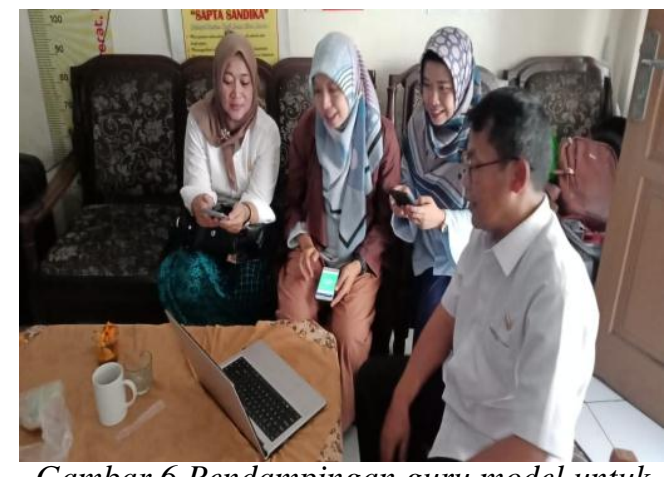

Gambar 6.Pendampingan guru model untuk mengimplementasikan model pembelajaran inovatif dan menggunakan media kahoot sebagai game based learning

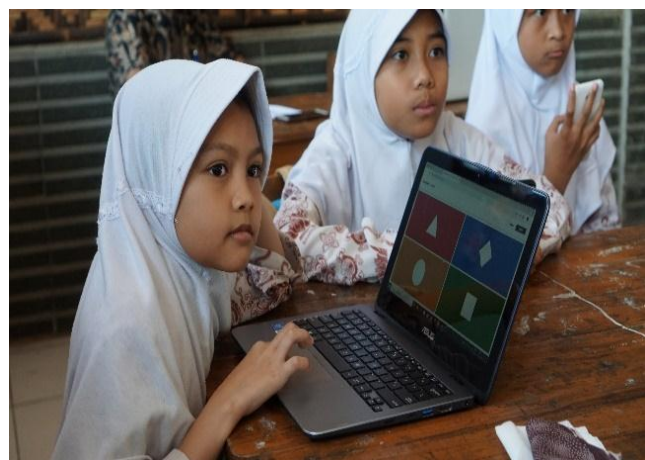

Gambar 7. Implementasi guru model dalam menerapkan kahoot pada pembelajaran

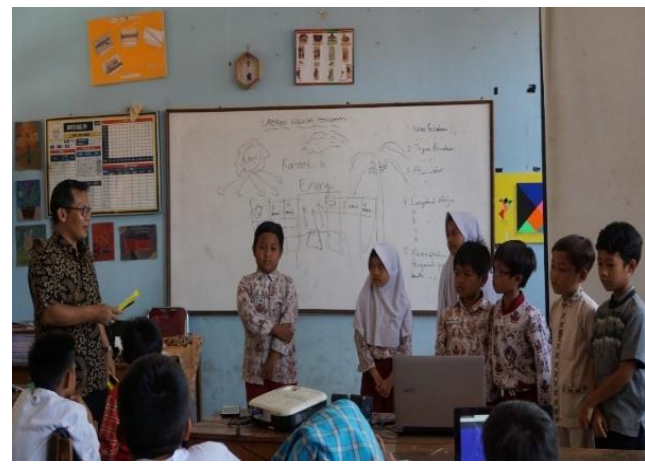

Gambar 8. Presentasi peserta didik dalam pembelajaran dengan model pembelajaran inovatif yang dilakukan guru

\section{KESIMPULAN \& SARAN}

Pelaksanaan kegaitan workshop dan pendampingan model-model pembelajaran inovatif dengan menggunakan literasi digital mengggunakan kahoot sebagai media games base learning di KKG Sekolah Dasar Kecamatan Lengkong Kota Bandung Provinsi Jawa Barat menimbulkan adanya 1) meningkatkan pengetahuan guru tentang model pembelajaran inovatif dan menggunakan kahoot dalam pembelajaran, 2) meningkatkan pengetahuan guru dalam membuat rencana pembelajaran (RPP) dan 3) meningkatkan keterampilan guru dalam menggunakan model pembelajaran inovatif dengan penggunakan media pembelajaran digital berbasis game. Selain itu, meningkatkan motivasi KKG untuk terus berkomitmen dalam menciptakan pembelajaran yang inovatif.

Guru sebaiknya lebih meningkatkan motivasi dan minatnya untuk menciptakan pembelajaran yang efektif dengan memilih model pembelajaran yang tepat sesuai dengan masalah pembelajarannya dan menerapkan literasi digital dengan media kahoot untuk meningkatkan motivasi belajar peserta didik serta saran yang diberikannya yaitu diperlukannya keseriusan pihak manajemen sekolah untuk lebih mengoptimalkan penggunaan adroid dan pemilihan model 
pembelajran inovatif yang dilakukan oleh guru sehingga proses pembelajaran menjadi lebih interaktif dan kondusif.

\section{UCAPAN TERIMA KASIH}

Penulis mengucapkan terima kasih kepada DRPM Dikti yang telah membiayai dan mendukung Hibah Pengabdian Masyarakat skema PKM tahun 2019 serta kepada LPM Universitas Pasundan dan FKIP Universitas Pasundan yang selalu memberikan motivasi dan dukungan untuk terus berkarya dalam melaksanakan kegiatan pengabdian kepada masyarakat.

\section{DAFTAR PUSTAKA}

Bennett, W. L. (2018). Changing Citizenship in the Digital Age. Civic Life Online, 124.

https://doi.org/10.7551/mitpress/7893.00 3.0002

Irwan, Irwan, Z. F. L., \& Waldi, A. (2019). Efektifitas Penggunaan Kahoot! untuk Meningkatkan Hasil Belajar Siswa [Effectiveness of Using Kahoot! to Improve Student Learning Outcomes]. PEDAGOGIA: Jurnal Pendidikan, 8(1), 95.

https://doi.org/10.21070/pedagogia.v8i1. 1866

Kereluik, K., Mishra, P., Fahnoe, C., \& Terry, L. (2013). What Knowledge Is of Most Worth. Journal of Digital Learning in Teacher Education, 29(4), 127-140. https://doi.org/10.1080/21532974.2013.1 0784716

Lee, Y. (2011). A Case Study on the Effect of Teaching Innovation on Learning Effectiveness: Using a Moderator of "Integrating Information Technology into Teaching." Journal of Human Resources \& Adult Learning, 7(1), 34.

Naga Subramani, P. C., \& Iyappan, V. (2018). Innovative methods of Teaching and Learning. Journal of Applied and Advanced Research, 3(S1), 20. https://doi.org/10.21839/jaar.2018.v3is1. 161

Naz, F., \& Murad, H. S. (2017). Innovative teaching has a positive impact on the performance of diverse students. SAGE
Open, 7(4).

https://doi.org/10.1177/21582440177340 22

Putri, A. R. \&, \& Muhammad Alie Muzakki. (2019). Implemetasi Kahoot sebagai Media Pembelajaran Berbasis Digital Game Based Learning dalam Mengahadapi Era Revolusi Industri 4.0. Prosiding Seminar Nasional Universitas Muria Kudus, 1-7. https://docplayer.info/147482653

Rofiyarti, F. \& A. Y. S. (2017). PEDAGOGI: Jurnal Anak Usia Dini dan Pendidikan Anak Usia Dini. Pedagogi: Jurnal Anak Usia Dini Dan Pendidikan Anak Usia Dini, 3(3a), 72-77.

Sugiarni, R., \& Kurniawati, dam N. (2019). R Sugiarni. Jurnal Qardhul Hasan: Media Pengabdian Kepada Masyarakat, 5(2), 83-89.

Tuken, R. (2013). IbM ALAT BANTU DAN SUMBER BELAJAR DALAM PEMBELAJARAN PKn DI SEKOLAH DASAR PADA GURU-GURU SEKOLAH DASAR YANG STUDI LANJUT DI PGSD UPP PAREPARE. Jurnal Publikasi Pendidikan, III(1), 6266.

Yuliati, S. R. \& I. L. (2018). PELATIHAN MODEL-MODEL PEMBELAJARAN INOVATIF SUKAMAKMUR, BOGOR Siti Rohmi Yuliati \& Ika Lestari Pendidikan Guru Sekolah Dasar , Universitas Negeri Jakarta INNOVATIVE INSTRUCTIONAL MODELS FOR ELEMANTARY. Jurnal Pemberdayaan Sekolah (JPSD), 2018(1), 2-7.

Zain, I. M. (2017). ASIE model: An innovative instructional design model for teachers in enhancing and sustaining the quality of the 21st century learning. ICSIT 2017 8th International Conference on Society and Information Technologies, Proceedings, 2017-March(2), 140-145. 